\title{
Evaluating Analytical Procedures for Quantifying Ammonium in Leaf Tissue
}

\author{
Anwar G. Ali ${ }^{1}$ and Carol J. Lovatt ${ }^{2}$ \\ Department of Botany and Plant Sciences, University of California, Riverside, CA 92521-0124
}

Additional index words. Citrus sinensis, amino acid contamination, electrical conductance, colorimetric, distillation

\begin{abstract}
The effects of different methods of sample preparation, extraction, and storage on the recovery of the combined pool of ammonia plus ammonium $\left(\mathrm{NH}_{3}+\mathrm{NH}_{4}^{+}\right)$from 'Washington' navel orange leaves previously incubated in solutions of increasing $\mathrm{NH}_{4} \mathrm{Cl}$ concentrations were assessed. Procedures and instruments for quantifying $\mathbf{N H}_{3}+\mathbf{N H}_{4}{ }^{+}$were tested for their sensitivity, reproducibility, and freedom from interference by amino acids. Reliable recoveries of $\mathrm{NH}_{3}+\mathrm{NH}_{4}^{+}$, free from amino acid interference, were obtained with oven-dried (60C) leaves ground to pass through a 40-mesh screen, extracted by homogenization in $10 \%$ TCA or by shaking in $2 \%$ acetic acid, and then filtered and analyzed on the basis of differences in electrical conductance between the sample and the reference cell. Methods measuring $\mathrm{NH}_{3}+\mathrm{NH}_{4}^{+}$in $\mathrm{KCl}$ extracts by reaction with salicylate-nitroprusside in the presence of hypochlorite were compromised by significant color formation due to amino acids. Using fresh or freeze-dried leaf samples resulted in lower recoveries than use of oven-dried samples. Storage at $\mathbf{- 2 0 C}$ of fresh or oven-dried leaf samples in $10 \%$ TCA before or after homogenization and filtration did not alter $\mathrm{NH}_{3}+\mathrm{NH}_{4}^{+}$levels, whereas storage of these samples at $4 \mathrm{C}$ increased $\mathrm{NH}_{3}+\mathrm{NH}_{4}^{+}$levels.
\end{abstract}

Concentrations of the combined pool of ammonia plus ammonium $\left(\mathrm{NH}_{3}+\mathrm{NH}_{4}^{+}\right)$in plant tissues are determined with increasing frequency by researchers and commercial laboratories. Total nitrogen content of plant tissue is routinely used as the basis for nitrogen fertilization recommendations, analysis of the nutritional quality of forage crops, and in research. The standard method for measuring total nitrogen is that of Kjeldahl (Bremner, 1965), which is based on quantitation of ammonium in an acid-digested sample or its distillate. Development of ammoniacal and urea fertilizers for soil and foliar nitrogen fertilization of crops has increased the demand for analysis of $\mathrm{NH}_{3}+\mathrm{NH}_{4}^{+}$in plant tissue samples. Brown and Zhang (1993) assessed ammonium accumulation in leaves as a diagnostic measure of optimal nitrogen fertilization of nectarines and almonds.

In addition, an increasing number of reports in the literature document that $\mathrm{NH}_{3}+\mathrm{NH}_{4}^{+}$accumulates in plant tissues in response to abiotic stresses. For example, Frota and Tucker (1978) reported that bean (Phaseolus vulgaris) plants receiving $\left({ }^{15} \mathrm{NH}_{4}\right) \mathrm{SO}_{4}$ accumulated ${ }^{15} \mathrm{NH}_{4}^{+}$when the plants were subjected to salinity or waterdeficit stress. Subsequently, Nilsen and Muller (1981) reported that ammonium accumulated in the roots of Lotus scoparius during water-deficit stress, and Flores and Galston (1982) added a note in proof that free ammonium titers increased in oat seedlings during wilting. Accumulation of $\mathrm{NH}_{4}^{+}$during mineral nutrient deficiencies of several plant species (Rabe and Lovatt, 1986; Feng and Barker, 1992a, 1992b), low-temperature and water-deficit stress of citrus cultivars (Lovatt et al., 1988a, 1988b), and salinity stress of

Received for publication 18 Nov. 1994. Accepted for publication 10 Apr. 1995. This paper is a portion of the dissertation submitted by A.G.A. in partial fulfillment of the requirements for the $\mathrm{PhD}$ in Botany at the Univ. of California. The research was supported in part by the Univ. of California Water Resources Center, as part of project UCAL-WRC-W-756, by matching funds from the Citrus Research Board, by a gift from Unocal Corp., by BARD grant I-643-89, and by the Citrus Research Center and Agricultural Experiment Station of the Univ. of California, Riverside. We thank Allen Barker and Etienne Rabe for instructing A.G.A. in the use of the distillation and salicylate methods, respectively. We also thank Anthony Hall and Mikeal Roose for their critical review of the manuscript. A.G.A. expresses his appreciation to the Univ. of Khartoum, Sudan. The cost of publishing this paper was defrayed in part by the payment of page charges. Under postal regulations, this paper therefore must be hereby marked advertisement solely to indicate this fact. ${ }^{\mathrm{I}} \mathrm{PhD}$ candidate, Univ. of California.

${ }^{2}$ Associate professor of plant physiology. muskmelon (Adler and Wilcox, 1988) has also been demonstrated. Methods currently used for quantifying $\mathrm{NH},+\mathrm{NH},+$ in plant tissues were adapted from those used in analyzing biological fluids, water, or soil extracts. Reaction of ammonia with phenol in the presence of an oxidizing agent such as hypochlorite to produce an intense blue color, first described by Berthelot (1859), has been used to quantify ammonia in urine, blood, and tissue fluids (Harrow et al., 1933; Van Slyke and Hiller, 1933). Lubochinsky and Zalta (1954) improved the sensitivity of the method by introducing sodium nitroprusside as a catalyst in the reaction between ammonia and phenol for determining ammonia in rat tissues and human plasma. The modified method was subsequently used for analyzing whole blood (McCullough, 1967) and soil extracts (Kempers, 1974; Selmer-Olsen, 1971). Reardon et al. (1966) replaced noxious phenol with salicylate, which yielded an emerald green color as ammonia at basic $\mathrm{pH}$ reacted with salicylate in the presence of hypochlorite. This method was then used to measure ammonia derived from urea in biological fluids (Seamy et al., 1967) animal feeds (Wall and Gehrke, 1975; Wall et al., 1975), and soil extracts (Nelson, 1983). Due to increased demand for ammonia quantitation in medicine and agriculture in recent years, instruments have been developed for the automated analysis many samples colorimetritally or by electrical conductance.

In this communication, we used common procedures reported in the literature in the manner in which they are routinely used for quantifying $\mathrm{NH}_{3}+\mathrm{NH}_{4}^{+}$and compared their sensitivity, reproducibility, and freedom from interference by amino acids. Reliability of these procedures was not known. The sensitivity of each method reported in the Materials and Methods was determined experimentally as part of this study. In addition, we report the effects of different methods of tissue preparation, extraction, and storage on the recovery of $\mathrm{NH}_{3}+\mathrm{NH}_{4}^{+}$from citrus leaves incubated in solutions of increasing concentrations of $\mathrm{NH}_{4} \mathrm{Cl}$ to provide a range of tissue $\mathrm{NH},+\mathrm{NH},+$ concentrations.

\section{Materials and Methods}

\section{Chemicals}

Trichloroacetic acid (TCA) was purchased from Fisher Scientific (Pittsburgh). Amino acid standards (Sigma UltraPure, 99\% by TLC; $\mathrm{NH}_{4}^{+}<0.05 \%$ ) and all other chemicals used in this study 
were purchased from Sigma Chemical Co. (St. Louis). All solutions were made with ammonia-free deionized water. Whatman no. 1 filter paper was routinely analyzed for $\mathrm{NH}_{3}+\mathrm{NH}_{4}^{+}$using the extractant in each analytical procedure described below. The respective extractants in each procedure were used to prepare the standards.

\section{Plant material}

Mature leaves were collected from 30-year-old 'Washington' navel orange (Citrus sinensis L. Osbeck) or lemon scions (Citrus limon L. Burm. f.) on Troyer citrange rootstock (C. sinensis $\mathrm{x}$ Poncirus trifoliata L. Raf.) located at the Univ. of California, Riverside, Agricultural Experiment Station. The leaves were washed with soapy water and rinsed thoroughly with distilled water. The leaf samples used in all subsequent analyses were from one of the following two groups.

Group I. Collected leaves were divided into three aliquots, which were analyzed as fresh tissue or after being oven-dried at $60 \mathrm{C}$ for $72 \mathrm{~h}$ or freeze-dried. Dried samples were ground in a Wiley mill to pass through a 40-mesh screen.

Group II. The upper portion of the leaf was excised $5 \mathrm{~mm}$ above the petiole, and the excised portion was rolled and inserted vertically into holes in the lid of a polyurethane box $(38 \times 14 \times 14-\mathrm{cm}$, 5.5-liter) containing aerated $\mathrm{NH}_{4} \mathrm{Cl}$ solutions (0 to $200 \mathrm{~mm}$ ) maintained at 5.5 liters by daily addition of distilled water to insure that the cut ends of the leaves were immersed in the solutions at all times. The boxes were placed in a growth chamber at $30 \mathrm{C}$ under continuous illumination (PFD of $310 \mu \mathrm{mol} \cdot \mathrm{m}^{-2} \cdot \mathrm{s}^{-1}$ ). At the end of $48 \mathrm{~h}$ the leaves were collected, washed thoroughly, blot-dried, cut into pieces ( 5 x 5 $\mathrm{mm}$, midvein removed) and analyzed as either i) fresh tissue or ii) after being oven-dried at $60 \mathrm{C}$ for $72 \mathrm{~h}$ or freeze-dried and ground with a Wiley mill to pass through a 40-mesh screen.

\section{Quantitation of amino acid contamination}

To determine whether any of the methods falsely detected amino acids as ammonia or caused their degradation and release of ammonia, commercial ammonia-free amino acid standards were analyzed. The amino acids and concentrations tested were those previously quantified by Rabe and Lovatt (1984) when leaf $\mathrm{NH}_{3}+$ $\mathrm{NH}_{4}^{+}$content increased in young fully expanded leaves of 7month-old phosphorus-deficient rough lemon seedlings (Citrus limon) (concentration, in $\mu \mathrm{g}$ amino acid/g dry weight citrus leaves, in parentheses): glutamine (346), glutamate (348), arginine (6970), omithine (6745), citrulline (7009), proline (20937), serine (17313), lysine (10837), glycine (1307), and asparagine (2996). Samples were diluted before analysis to represent the amount of dry leaf sample typically analyzed by each procedure. Dilutions were made with the extractant used in each method.

\section{Analytical procedures}

Technicon autoanalyzer. By this method (method no. 329-74; Technicon Industrial Systems, Tarrytown, N.Y.), ammonia is determined calorimetrically based on the reaction of sodium salicylate-sodium nitroprusside with ammonia in the presence of hypochlorite to form a blue color. The combined pool of $\mathrm{NH},+$ $\mathrm{NH}_{4}^{+}$was measured in a 200-mg oven-dried sample. The sample was extracted in $50 \mathrm{ml} 1 \mathrm{~N} \mathrm{KC1}$ by shaking in a reciprocal shaker for $30 \mathrm{~min}$ and filtered through Whatman no. 1 filter paper. The assay was linear for concentrations of ammonium between 0 and $100 \mu \mathrm{g} \cdot \mathrm{ml}^{-1}$. Sample filtrates were diluted with $1 \mathrm{~N} \mathrm{KC1}$ to give values in this range.

Salicylate method. The method of Nelson (1983) for the analysis of soil ammonia by reaction with salicylate to form an emerald green color in the presence of sodium hypochlorite at $\mathrm{pH} 13$ was modified by E. Rabe (Univ. of Stellenbosch, South Africa, personal communication) for analysis of ammonia in plant tissue. Rabe eliminated ethylenediaminetetraacetic acid (EDTA) from the reaction mixture, and leaf samples were extracted in $1 \mathbf{N ~ K C 1}$ as in the Technicon method instead of $2 \mathrm{~N} \mathrm{KC1}$ (Nelson, 1983).

A 500-mg oven-dried leaf sample was extracted in $50 \mathrm{ml} 1 \mathrm{~N}$ $\mathrm{KCl}$ by reciprocal shaking for $30 \mathrm{~min}$. The homogenate was filtered through Whatman no. 1 filter paper, $2.5 \mathrm{ml}$ of filtrate fraction was transferred to a 50-ml volumetric flask containing 2.5 $\mathrm{ml} 1 \mathrm{~N} \mathrm{KCl}$ and mixed gently, and $4 \mathrm{ml}$ of a solution of $78 \%(\mathrm{w} / \mathrm{v})$ sodium salicylate and $0.10 \%(\mathrm{w} / \mathrm{v})$ sodium nitroprusside was added. After mixing thoroughly, $13 \mathrm{ml}$ of deionized water was added to the sample followed by the addition of $2 \mathrm{ml}$ of buffer comprised of $3 \%(\mathrm{w} / \mathrm{v})$ sodium hydroxide, $7.5 \%(\mathrm{w} / \mathrm{v})$ sodium phosphate, and $0.7 \%$ (v/v) sodium hypochlorite, adjusted to $\mathrm{pH} 13$ with $\mathrm{NaOH}$. The solution was incubated for $30 \mathrm{~min}$ in a waterbath at $37 \mathrm{C}$ and cooled to room temperature, and absorbance at $667 \mathrm{~nm}$ was determined. The $\mathrm{A}_{667 \mathrm{~mm}}$ was linear for $\mathrm{NH},+\mathrm{NH},+$ concentrations between 0 and $0.5 \mu \mathrm{g} \cdot \mathrm{ml}^{-1}$. Sample filtrates were diluted with $1 \mathrm{~N} \mathrm{KC1}$ to give values in this range.

Distillation method. This method is a modification of the Kjeldahl method (Bremner, 1965). Sample digestion is eliminated. Ammonia in the undigested sample is released by distillation at a basic $\mathrm{pH}$ using $\mathrm{NaOH}$ instead of $\mathrm{MgO}$, collected in a standard acid, and quantified by titration with potassium biiodate rather than sulfuric acid (Barker and Volk, 1964).

One gram fresh weight of 'Washington' navel orange leaves was homogenized with a Polytron tissue homogenizer (PCU, Brinkman Instruments, Westbury, N.Y.) in $10 \mathrm{ml} 1 \mathrm{~N} \mathrm{KC1}$ containing $0.025 \mathrm{M} \mathrm{CuSO}_{4}$ and centrifuged, and the resulting supernatant was filtered through Whatman no. 1 filter paper. The ammonia content of the filtrate was measured after about $36 \mathrm{~h}$ storage on ice. For comparison, $1 \mathrm{~g}$ oven-dried or freeze-dried leaf samples were extracted in $50 \mathrm{ml} 1 \mathrm{~N} \mathrm{KC1}$ containing $0.025 \mathrm{M} \mathrm{CuSO}_{4}$ by shaking in a reciprocal shaker for $30 \mathrm{~min}$. The samples were filtered through Whatman no. 1 filter paper, and the filtrate was transferred to a $100-\mathrm{ml}$ Kjeldahl flask.

In each case, $10 \mathrm{ml} 40 \%(\mathrm{w} / \mathrm{v}) \mathrm{NaOH}$ was added slowly to the filtrate, and steam was allowed to pass through the samples. The heat generated by the steam passing through the distillation unit and the high $\mathrm{pH}$ maintained by the $\mathrm{NaOH}$ resulted in the formation of ammonia gas, which was subsequently condensed and collected in a 125-ml Erlenmeyer flask containing $10 \mathrm{ml} \mathrm{2 \% (w/v)} \mathrm{boric}$ acid-indicator solution. The boric acid-indicator solution was prepared by adding $6.7 \mathrm{ml} 0.2 \%(\mathrm{w} / \mathrm{v})$ methyl red in $95 \%$ ethanol and $3.3 \mathrm{ml} 0.2 \%(\mathrm{w} / \mathrm{v})$ methylene blue in $95 \%(\mathrm{v} / \mathrm{v})$ ethanol to $2 \%$ boric acid solution at final volume of one liter. The purple color of the absorbing solution changed to green in the presence of ammonia. Complete distillation of a sample took 7 to $10 \mathrm{~min}$. The distillate was titrated with $0.014 \mathrm{M}$ potassium biiodate until the color reverted back to the original purple color. The volume of the titrant was recorded, and the ammonia in the sample was calculated (Barker and Volk, 1964):

$\mu \mathrm{g} \mathrm{NH} \mathrm{NH}_{4}-\mathrm{N} / \mathrm{g}=(0.2 \mathrm{mg}$ nitrogen $/ \mathrm{ml}$ acid $) \times \mathrm{ml}$ titrant $\mathrm{KH}\left(\mathrm{IO}_{3}\right)_{2} /$ sample weight $(\mathrm{g})$.

Wescan ammonia analyzer and Alltech inorganic nitrogen analyzer. The Wescan ammonia analyzer (model 360; Alltech Associates, Deerfield, Ill.) and Alltech inorganic nitrogen analyzer (model 380; Alltech Associates) use a strong base, $11.3 \%(\mathrm{w} / \mathrm{v})$ potassium hydroxide plus $1 \%(\mathrm{w} / \mathrm{v})$ diethylenetriamine-pentaacetic acid (DTPA) to maintain the $\mathrm{pH}$ of the sample between 11 and 13 to convert all the ammonium ion present in the sample to ammonia 
gas, which diffuses across a membrane and dissolves in the absorbing solution [ $1 \%(\mathrm{w} / \mathrm{v})$ boric acid or deionized water for the two instruments, respectively]. The difference in the electrical conductance between the sample and reference cell is proportional to the ammonium concentrations in the sample (Carlson, 1978). The following flow rates $\left(\mathrm{ml} \cdot \mathrm{min}^{-1}\right)$ were used: sample, 1.32 ; base, 5.2; and absorbing solution, 1.32. The assay is linear for ammonium concentrations between 0 and $100 \mu \mathrm{g} \cdot \mathrm{ml}^{-1}$. Sample filtrates were diluted with their respective extracts (see below) to give values in this range.

Tissue extraction. Extractants and procedures commonly used for quantitating $\mathrm{NH}_{3}+\mathrm{NH}_{4}^{+}$by electrical conductance (Wescan and Alltech) were compared. A 50-mg (dry weight) oven-dried leaf sample was extracted in either i) $50 \mathrm{ml} 2 \%(\mathrm{v} / \mathrm{v})$ acetic acid or ii) $1 \mathrm{~N} \mathrm{KC1}$ by shaking for $10 \mathrm{~min}$ with a reciprocal shaker. With a 50-mg (dry weight) sample, shaking for $10 \mathrm{~min}$ in either extractant gave maximum recovery. In addition, fresh (1 $\mathrm{g}$ fresh weight), freeze-dried ( $1 \mathrm{~g}$ dry weight), or oven-dried ( $1 \mathrm{~g}$ dry weight) leaf samples were homogenized for $1 \mathrm{~min}$ in $5 \mathrm{ml} \mathrm{10 \%} \mathrm{(w/v)} \mathrm{TCA} \mathrm{with}$ a Polytron tissue homogenizer. The probe was rinsed with $5 \mathrm{ml}$ $10 \%$ TCA, which was added to the homogenate. The homogenate was centrifuged at $10,000 \times \mathrm{g}$ at $4 \mathrm{C}$ for $10 \mathrm{~min}$ and filtered through Whatman no. 1 filter paper.

Sample storage. In anticipation of analyzing many samples, we evaluated possible points at which sample processing could be interrupted and the temperature at which samples could be stored without any negative effect on $\mathrm{NH}_{3}+\mathrm{NH}_{4}{ }^{+}$content.

Three grams of fresh 'Washington' navel orange leaves (midvein removed) or $1.5 \mathrm{~g}$ of oven-dried leaves were homogenized for 1 min with a Polytron tissue homogenizer in $15 \mathrm{ml} \mathrm{10 \%} \mathrm{TCA.} \mathrm{The}$ probe was rinsed with $15 \mathrm{ml} 10 \%$ TCA, which was added to the homogenate. The homogenate was centrifuged at $10,000 \times \mathrm{g}$ at $4 \mathrm{C}$ for $10 \mathrm{~min}$ and filtered through Whatman no. 1 filter paper. The filtrate was divided into three aliquots, which were processed as follows: i) analyzed immediately; ii) stored in a freezer (-20C) and analyzed at the end of 1 week, iii) stored in a refrigerator (4C) and analyzed for $\mathrm{NH}_{3}+\mathrm{NH}_{4}^{+}$at the end of 1 week.

In addition, $1 \mathrm{~g}$ of fresh 'Washington' navel orange leaves (midvein removed) was cut into pieces $(5 \times 5 \mathrm{~mm})$ or $500 \mathrm{mg}$ of oven-dried leaf samples was suspended in $5 \mathrm{ml} \mathrm{10 \%} \mathrm{TCA} \mathrm{and}$ stored at 4 or $-20 \mathrm{C}$. After 1 week, the samples were homogenized with a tissue homogenizer and the probe was rinsed with $5 \mathrm{ml}$ of $10 \%$ TCA, which was added to the homogenate. The homogenate was centrifuged and filtered, and the ammonium content of the filtered acid soluble supernatant fraction was determined.

Presentation of data. The five analytical procedures used in this study quantify the combined pool of $\mathrm{NH},+\mathrm{NH},+$ as either $\mathrm{NH}$, or $\mathrm{NH},+$. For comparison, all results are presented as $\mu \mathrm{g} \mathrm{NH}_{4}^{+} / \mathrm{g}$ fresh or dry weight tissue.

\section{Results}

$\mathrm{NH}_{3}+\mathrm{NH}_{4}^{+}$content of a series of oven-dried standard leaf samples prepared by incubating leaves of the 'Washington' navel orange in $\mathrm{NH}_{4} \mathrm{Cl}$ solutions from 0 to $200 \mathrm{~mm}$ for $48 \mathrm{~h}$ was determined using five analytic procedures: Technicon autoanalyzer, salicylate method, distillation, Wescan ammonia analyzer, and Alltech inorganic nitrogen analyzer. The results obtained with all five procedures differed quantitatively (Fig. 1). Despite the fact that samples were diluted to give values within the range of $\mathrm{NH}$, $+\mathrm{NH}_{4}{ }^{+}$concentrations optimal for each method, the Technicon method was insensitive at the lower concentrations of $\mathrm{NH}_{4}^{+}$, and the salicylate method was insensitive at lower and higher concen- trations of $\mathrm{NH}, `$ The $\mathrm{NH}_{3}+\mathrm{NH}_{4}^{+}$content of the leaves assessed by the distillation procedure was significantly 2 -fold greater than the Wescan ammonia analyzer, which was 1.6 to 1.8 -fold greater than the Alltech inorganic nitrogen analyzer $(P \leq 0.05)$. No difference between the $\mathrm{NH},+\mathrm{NH},+$ content of the control leaves incubated in distilled water and that of leaves incubated in $12.5 \mathrm{mM} \mathrm{NH}_{4} \mathrm{Cl}$ for $48 \mathrm{~h}$ was detected by any method, but all methods approximated $2500 \mu \mathrm{g} \mathrm{NH}+\mathrm{NH}_{4}^{+} / \mathrm{g}$ dry weight for the $200 \mathrm{mM} \mathrm{NH}_{4} \mathrm{Cl}$ treatment, except the salicylate method, by which only $1307 \pm 24 \mu \mathrm{g} \mathrm{NH}_{3}+$ $\mathrm{NH}_{4}^{+} / \mathrm{g}$ dry weight was detected.

Detection of amino acids as $\mathrm{NH}_{3}+\mathrm{NH}_{4}^{+}$by five analytic methods. Only the two procedures using electrical conductance did not detect amino acids as $\mathrm{NH}_{3}+\mathrm{NH}_{4}^{+}$(Table 1). Results obtained with the Technicon autoanalyzer procedure were the most severely contaminated, detecting a net difference of $6168 \mu \mathrm{g} \cdot \mathrm{g}^{-1}$ dry weight (386-fold) more $\mathrm{NH},+\mathrm{NH}$,' than the least compromised method, the Wescan ammonia analyzer $\left(16 \mu \mathrm{g} \cdot \mathrm{g}^{-1}\right)$. By the salicylate method, $1453 \mu \mathrm{g} \cdot \mathrm{g}^{-1}$ dry weight (92-fold) more $\mathrm{NH}_{3}+\mathrm{NH}_{4}^{+}$was detected compared to the Wescan ammonia analyzer; for the distillation the difference was only $172 \mu \mathrm{g} \cdot \mathrm{g}^{-1}$ dry weight.

Effect of leaf preparation method on the concentration of $\mathrm{NH}_{3}$ $+\mathrm{NH}_{4}^{+}$determined. Regardless of the method of $\mathrm{NH}_{3}+\mathrm{NH}_{4}^{+}$ analysis used, i.e., electrical conductance (Table 2) or distillation (Table 3), greater concentrations of $\mathrm{NH}_{3}+\mathrm{NH}_{4}{ }^{+}$were detected in oven-dried leaf samples compared to aliquots of the same leaves analyzed after freeze drying or immediately upon collection as fresh samples. Leaf $\mathrm{NH}_{3}+\mathrm{NH}_{4}{ }^{+}$was found to be evenly distributed within the leaf; e.g., apical and basal halves of leaves had equal concentrations. The midvein, about $10 \%$ of the total fresh weight of citrus leaves, contributed $<10 \%$ of the $\mathrm{NH}_{3}+\mathrm{NH}_{4}^{+}$content of the leaf per gram fresh weight.

Effect of extractant and extraction procedure on leaf $\mathrm{NH}_{3}+$ $\mathrm{NH}_{4}^{+}$content. The $\mathrm{NH}_{3}+\mathrm{NH}_{4}^{+}$content of leaves incubated in $\mathrm{NH}_{4} \mathrm{Cl}$ solutions (0 to $200 \mathrm{~mm}$ ) was determined by Wescan ammonia analyzer for a 50-mg oven-dried sample extracted in either $50 \mathrm{ml} 2 \%$ acetic acid or $50 \mathrm{ml} 1 \mathrm{~N} \mathrm{KC1}$ by shaking with a

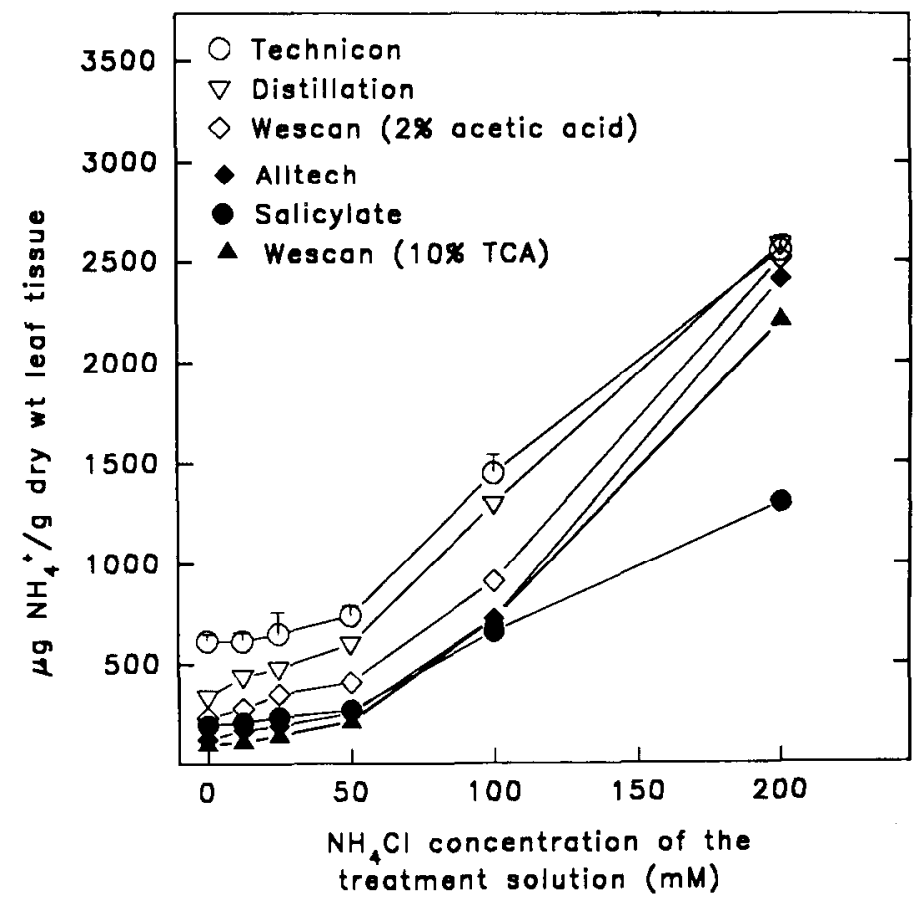

Fig. 1. $\mathrm{NH}_{3}+\mathrm{NH}_{4}^{+}$content of citrus leaves previously incubated in $\mathrm{NH}_{4} \mathrm{Cl}$ solutions from 0 to $200 \mathrm{~mm}$ for $48 \mathrm{~h}$ determined by six analytical procedures. Vertical bars at given concentrations of $\mathrm{NH}_{4} \mathrm{Cl}$ represent LSD at $P \leq 0.05$. 
reciprocal shaker for $10 \mathrm{~min}$ or for a 500-mg oven-dried sample extracted in $10 \mathrm{ml} 10 \%$ TCA by homogenization with a Polytron tissue homogenizer. $\mathrm{No} \mathrm{NH}_{3}+\mathrm{NH}_{4}^{+}$was detected in leaves incubated in low concentrations of $\mathrm{NH}_{4} \mathrm{Cl}(0$ to $50 \mathrm{~mm})$ when they were extracted by shaking in $\mathrm{KCl}$. Even at greater concentrations of $\mathrm{NH}_{4} \mathrm{Cl}(100$ and $200 \mathrm{~mm})$, lower amounts of $\mathrm{NH},+\mathrm{NH},+$ were generally recovered by extraction in $\mathrm{KC} 1$ than in $2 \%$ acetic acid or $10 \%$ TCA (Fig. 2). Leaves extracted in 10\% TCA with a Polytron tissue homogenizer for about 1 min yielded significantly lower concentrations of $\mathrm{NH}_{3}+\mathrm{NH}_{4}^{+}$than extraction in $2 \%$ acetic acid by shaking for $10 \mathrm{~min}$ (Fig 2).

Effect of sample processing on $\mathrm{NH}_{3}+\mathrm{NH}_{4}^{+}$content. The $\mathrm{NH}_{3}$ $+\mathrm{NH}_{4}^{+}$content of fresh leaves cut into $5 \times 5$-mm pieces and stored in $10 \%$ TCA at $4 \mathrm{C}$ for 1 week increased $100 \%$, whereas the $\mathrm{NH}_{3}+\mathrm{NH}_{4}^{+}$ content of the same sample stored in 10\% TCA at -20C for 1 week was not affected (Table 4). In contrast, storage of the filtered homogenate of fresh leaves for 1 week at $4 \mathrm{C}$ resulted in only a $50 \%$

Table 1. Amino acids detected as $\mathrm{NH}_{3}+\mathrm{NH}_{4}^{+}$by five analytic methods.

\begin{tabular}{lccc}
\hline \hline Method & $\begin{array}{c}\text { Individual amino } \\
\text { acids detected }\end{array}$ & & $\begin{array}{c}\text { Total } \mathrm{NH}_{3}+\mathrm{NH}_{4}^{+} \\
\text {detected from } \\
\text { as } \mathrm{NH}_{3}+\mathrm{NH}_{4}^{+2}\end{array}$ \\
the mixture
\end{tabular}

${ }^{\overline{2}}$ Commercial amino acid standards (Sigma, $99^{+} \%$ pure by TLC) were prepared at concentrations equal to those found in young fully expanded leaves of 7-month-old phosphorus-deficient rough lemon (Citrus limon) seedlings (expressed as $\mu \mathrm{g} \cdot \mathrm{g}^{-1}$ dry wt leaf tissue) which accumulated $\mathrm{NH}$, $+\mathrm{NH},+$ and contained 3.5 times the concentration of total free amino acids as leaves of healthy, nonstressed seedlings (Rabe and Lovatt, 1984). Amino acids ( $\mu \mathrm{g} \cdot \mathrm{g}^{-1}$ dry wt) tested were glutamine (346), glutamate (348), arginine (6970), omithine (6745), citrulline (7009), proline (20937), serine (17313), lysine (10837), glycine (1307), and asparagine (2996). Samples were diluted before analysis to represent the amount of dry leaf sample typically analyzed by each procedure. Amino acids listed in the table contributed the greatest proportion of the contamination. The data are the means of two separate experiments. The difference between replicates was a maximum of $20 \%$ for the Technicon method and a minimum of $7 \%$ for the Alltech method. increase in leaf $\mathrm{NH}_{3}+\mathrm{NH}_{4}^{+}$content. Storage of the filtered homogenate at $-20 \mathrm{C}$ for 1 week did not affect $\mathrm{NH}_{3}+\mathrm{NH}_{4}^{+}$content. The storage of ground oven-dried orange leaftissue in $10 \%$ TCA for 1 week at $4 \mathrm{C}$ resulted in a $20 \%$ increase in $\mathrm{NH}_{3}+\mathrm{NH}_{4}^{+}$content; freezing at $-20 \mathrm{C}$ for 1 week did not affect the $\mathrm{NH}_{3}+\mathrm{NH}_{4}^{+}$concentration of the samples (Table 5). Storage of the filtered homogenate of ovendried leaf samples at 4 or $-20 \mathrm{C}$ resulted in a slight (12\%) increase in leaf $\mathrm{NH}_{3}+\mathrm{NH}_{4}^{+}$concentration.

\section{Discussion}

Only the two procedures by which $\mathrm{NH}_{3}+\mathrm{NH}_{4}^{+}$was quantified based on changes in electrical conductance (Wescan and Alltech) were free from interference by amino acids. The Technicon method, which consistently measured much greater levels of $\mathrm{NH}_{3}+\mathrm{NH}_{4}^{+}$ for the leaves incubated with 0 to $200 \mathrm{mM} \mathrm{N} \mathrm{H}_{4} \mathrm{Cl}$, detected a significant amount of Glu + Gln, Asn, and citrulline. These particular amino acids have been reported to increase in concentration as the concentration of $\mathrm{NH}_{3}+\mathrm{NH}_{4}^{+}$increased (Rabe and Lovatt, 1984). The detection of significant amounts of several amino acids as $\mathrm{NH}_{3}+\mathrm{NH}_{4}{ }^{+}$by the Technicon procedure suggests that the high recovery of leaf- $\mathrm{NH}_{3}+\mathrm{NH}_{4}{ }^{+}$by this method was due to direct interference from amino acids or to ammonium released by their decomposition. Burton et al. (1989) previously reported that an automated Technicon Industrial method, which uses the Berthelot reaction (indophenol procedure), detected amino acids as ammonium, whereas no significant interference occurred with steam distillation. Surprisingly, the salicylate method, which yielded lower $\mathrm{NH}_{3}+\mathrm{NH}_{4}^{+}$recoveries than the distillation method and Wescan ammonia analyzer (using $2 \%$ acetic acid as the extractant) for each of the leaf samples in the series from 0 to $200 \mathrm{mM} \mathrm{NH}_{4} \mathrm{Cl}$, detected a significant number of amino acids as $\mathrm{NH}_{3}+\mathrm{NH}_{4}^{+}$. However, due to the lack of sensitivity of this method, the total amount of $\mathrm{NH}_{3}+\mathrm{NH}_{4}^{+}$detected was lower than that of the Technicon autoanalyzer. Most of the interference was from serine; nonetheless, amino acids (such as proline, arginine, and ornithine) known to accumulate in response to the same abiotic stresses that cause $\mathrm{NH}_{3}+\mathrm{NH}_{4}^{+}$to accumulate also compromised the salicylate method. Because this procedure was linear for $\mathrm{NH}_{3}+\mathrm{NH}_{4}^{+}$ concentrations up to only $0.5 \mu \mathrm{g} \cdot \mathrm{ml}^{-1}$, most samples would need to be diluted to give values in this range. Subsequent expression of the data per gram fresh or dry weight would magnify errors compared to methods that are linear for $\mathrm{NH}_{3}+\mathrm{NH}_{4}^{+}$concentrations up to 100 $\mu \mathrm{g} \cdot \mathrm{m}^{-1}$. Detection of amino acids as $\mathrm{NH}_{3}+\mathrm{NH}_{4}^{+}$by the distillation procedure was lower than the Technicon or the salicylate procedures. Bremner (1965) reported that distillation with $\mathrm{NaOH}$ caused decomposition of some organic $\mathrm{N}$ to $\mathrm{NH}_{4}^{+}$; use of $\mathrm{Mg0}$ minimized this result. Thus, it is possible that amino acid interference in the distillation procedure of Barker and Volk (1964) could be reduced if $\mathrm{NaOH}$ were replaced by $\mathrm{MgO}$. Previous research provided

Table 2. Effect of different methods of leaf preparation on $\mathrm{NH}_{3}+\mathrm{NH}_{4}^{+}$ content $^{2}$

\begin{tabular}{llll}
\hline & \multicolumn{3}{c}{ Leaf preparation method } \\
\cline { 2 - 4 } Species & Fresh & Freeze-dried & Oven-dried \\
\hline \multirow{3}{*}{ Citrus limon } & $\mathrm{NH}_{4}^{+} / g d r y$ & $w t$ & \\
Citrus sinensis & $46.0 \pm 0$ & $54.8 \pm 3.9$ & $85.6 \pm 1.6$ \\
& $28.8 \pm 0$ & $46.2 \pm 8.3$ & $106.7 \pm 0$
\end{tabular}

${ }^{2}$ In each case the leaf tissue was extracted by homogenization for one minute in $10 \mathrm{ml} 10 \%$ TCA with a Polytron tissue homogenizer. $\mathrm{NH}_{3}+$ $\mathrm{NH}_{4}^{+}$was quantified by electrical conductance using a Wescan ammonia analyzer. Data are the means \pm SE for three separate experiments. 
Table 3. Effect of different methods of leaf preparation on $\mathrm{NH}_{3}+\mathrm{NH}_{4}^{+}$content of 'Washington' navel orange leaves previously incubated in $\mathrm{NH}_{4} \mathrm{Cl}$ solutions from 0 to $200 \mathrm{~mm}$ for $48 \mathrm{~h}^{\mathrm{z}}$.

\begin{tabular}{|c|c|c|c|c|}
\hline \multirow{2}{*}{$\begin{array}{l}\mathrm{NH}_{4} \mathrm{Cl} \\
\text { treatment } \\
(\mathrm{mM})\end{array}$} & \multicolumn{3}{|c|}{ Leaf preparation method } & \multirow[b]{2}{*}{ Significance } \\
\hline & Fresh & Freeze-dried & Oven-dried & \\
\hline \multicolumn{5}{|c|}{$\mu g \mathrm{NH}_{4}^{+} / g d r y w t$} \\
\hline 0 (Control) & $278 \mathrm{~b}$ & $400 \mathrm{a}$ & $440 \mathrm{a}$ & $* *$ \\
\hline 6.5 & $406 \mathrm{~b}$ & $460 \mathrm{~b}$ & $580 \mathrm{a}$ & $* *$ \\
\hline 12.5 & $426 \mathrm{c}$ & $600 \mathrm{~b}$ & $680 a$ & $* * *$ \\
\hline 25.0 & $592 \mathrm{~b}$ & 899 a & $919 \mathrm{a}$ & $* * *$ \\
\hline 200.0 & $3198 \mathrm{c}$ & $5376 b$ & $6037 \mathrm{a}$ & $* * * *$ \\
\hline
\end{tabular}

${ }^{2}$ Detached citrus leaves were incubated in $\mathrm{NH}_{4} \mathrm{Cl}$ solutions from 0 to $200 \mathrm{mM}$, washed, oven-dried at $60 \mathrm{C}$ for $72 \mathrm{~h}$ and ground to pass through a 40-mesh screen. See Materials and Methods for details. $\mathrm{NH}_{3}+\mathrm{NH}_{4}^{+}$was quantified using the distillation method. means within a horizontal row with the same letter are not significantly different by Duncan's multiple range test at $P \leq 0.05$. Means within a horizontal row followed by different letters are significant at $P \leq 0.01(* *), 0.001(* * *)$, and $0.0001(* * * *)$, respectively.

evidence that air drying or oven drying soil samples affected the release of amino acids and increased the interference associated with calorimetric determination of ammonia (Monreal and McGill, 1985). Burton et al (1989) stated that amino acids were involved in producing higher estimates of ammonia by the indophenol method when soil samples were air-dried or oven-dried. The results of our research with leaf tissue are consistent with these reports. Greater concentrations of $\mathrm{NH}_{3}+\mathrm{NH}_{4}^{+}$were obtained with oven-dried vs. fresh or freeze-dried leaf samples, possibly due to degradation of amino acids in the tissue during drying at $60 \mathrm{C}$.

While there were differences in the estimates of leaf $\mathrm{NH},+$ $\mathrm{NH},+$ content for acetic acid vs. TCA extracts of the same leaf samples, the differences are not necessarily due to the extractant because the extraction volume and the length of extraction were different as well. Greater (about $113 \%$ to $242 \%$ ) recovery was obtained with the acetic acid procedure, suggesting that extracting a smaller sample $(50 \mathrm{mg})$ by shaking in a larger volume of extractant $(50 \mathrm{ml})$ for $10 \mathrm{~min}$ may be more effective than extracting $500 \mathrm{mg}$ of tissue in $10 \mathrm{ml}$ extractant by homogenization for only 1 min. Rigor of shaking, length of the stroke, and number of strokes per minute significantly affected the amount of $\mathrm{NH},+\mathrm{NH},+$ extracted. These need to be optimized for each plant species and tissue being analyzed over a range of $\mathrm{NH}_{3}+\mathrm{NH}_{4}^{+}$concentrations. In addition, it is unlikely that either acid caused amino acid decomposition. Acid-soluble fractions are routinely used for recovery and quantitation of amino acids and other organic nitrogen compounds. In addition, the standard procedure for hydrolyzing protein to determine its amino acid content requires extracting oven-dried ground leaf tissue in $6 \mathrm{~N} \mathrm{HCl}$ under vacuum at $110 \mathrm{C}$ for 22 h (Labanuaskas and Handy, 1971). When analyzing a large number of samples, fresh or oven-dried leaf samples can be stored at $-20 \mathrm{C}$ for 1 week in $5 \mathrm{ml} 10 \%$ TCA or after homogenization in $10 \mathrm{ml} 10 \%$ TCA and filtration without any effect on the $\mathrm{NH}_{3}+$ $\mathrm{NH}_{4}^{+}$content of the sample.

In conclusion, the method of quantifying $\mathrm{NH},+$ based on differences in electrical conductance between the sample and the reference cell developed by Carlson (1978) and incorporated into the Wescan ammonia analyzer and its successor, the Alltech inorganic nitrogen analyzer, is the most reliable analytic procedure of the four we tested. Interference from amino acids was minimal and significantly (lo-fold) lower than the next-best method, distillation (researchers with limited budgets or only occasional analyses might find the distillation method acceptable, especially after replacing $\mathrm{NaOH}$ with $\mathrm{MgO}$ in the distillation). The conductance method is linear for ammonium concentrations between 0 and 100 $\mu \mathrm{g} \cdot \mathrm{ml}^{-1}$; the results are highly reproducible as evidenced by the small standard errors from three separate experiments. The method is compatible with different extractants $(1 \mathrm{~N} \mathrm{KCl}, 2 \%$ acetic acid, and $10 \%$ TCA). The best recoveries of $\mathrm{NH}_{3}+\mathrm{NH}_{4}{ }^{+}$were obtained with oven-dried (60C) leaves ground to pass through a 40-mesh screen extracted by shaking in $2 \%$ acetic acid or by homogenization in $10 \%$ TCA. The latter extracting procedure can be used with fresh and dried (freeze-dried or oven-dried at 60C) leaf tissue and requires only $1 \mathrm{~min}$ of homogenization, facilitating the processing many samples. Of additional advantage, fresh or oven-dried samples can be stored at $-20 \mathrm{C}$ for one week in $10 \%$ TCA before homogenization or after homogenization and filtration without affecting the $\mathrm{NH}_{3}+\mathrm{NH}_{4}^{+}$content of the samples. Compatibility of the method with TCA is highly desirable, as the TCA acid-soluble fraction can be used concurrently for quantitative recovery and determination of leaf concentrations of amino acids, polyamines, and pyrimidine

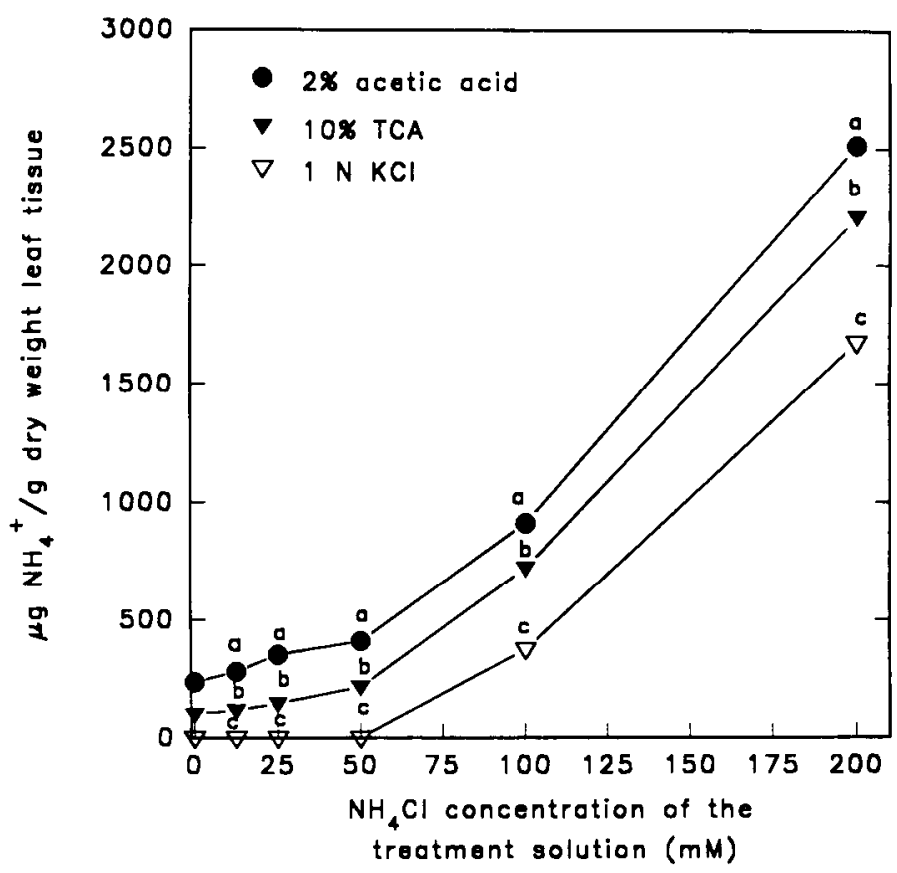

Fig. 2. Effect of extraction on $\mathrm{NH}_{3}+\mathrm{NH}_{4}{ }^{+}$content of oven-dried leaves of 'Washington' navel orange previously incubated in $\mathrm{NH}_{4} \mathrm{Cl}$ solutions from 0 to $200 \mathrm{~mm}$ for $48 \mathrm{~h} . \mathrm{NH}_{3}+\mathrm{NH}_{4}^{+}$was determined by electrical conductance using Wescan ammonia analyzer. Data points with different letters at given concentrations of $\mathrm{NH}_{4} \mathrm{Cl}$ represent significance at $P \leq 0.05$ by Duncan's multiple range test. 
Table 4. Effect of interruption of sample processing and storage for 1 week on $\mathrm{NH}_{3}+\mathrm{NH}_{4}^{+}$content of fresh 'Washington' navel orange leaves

\begin{tabular}{|c|c|c|}
\hline Treatment' & $\begin{array}{c}\text { Storage } \\
\text { temp } \\
\text { for } 1 \text { week }\end{array}$ & $\begin{array}{l}\mu \mathrm{g} \mathrm{NH}_{4}^{+} / \mathrm{g} \\
\text { fresh wt } \pm \mathrm{SE}\end{array}$ \\
\hline $\begin{array}{l}\text { Extracted ( } 1 \mathrm{~g} / 10 \mathrm{ml} \mathrm{10 \%} \text { TCA), } \\
\text { analyzed immediately (control) }\end{array}$ & Not stored & $16.0 \pm 0.8$ \\
\hline Not extracted ( $1 \mathrm{~g} / 5 \mathrm{ml} 10 \%$ TCA $)$ & $4 \mathrm{C}$ & $30.6 \pm 1.6$ \\
\hline Not extracted $(1 \mathrm{~g} / 5 \mathrm{ml} 10 \%$ TCA $)$ & $-20 \mathrm{C}$ & $16.6 \pm 0.8$ \\
\hline Extracted $(1 \mathrm{~g} / 10 \mathrm{ml} 10 \% \mathrm{TCA})$, filtered & $4 \mathrm{C}$ & $23.2 \pm 0.8$ \\
\hline Extracted $(1 \mathrm{~g} / 10 \mathrm{ml} 10 \%$ TCA $)$, filtered & $-20 \mathrm{C}$ & $16.6 \pm 0.8$ \\
\hline
\end{tabular}

Leaves collected and washed as described in Materials and Methods, were cut and stored or processed through homogenization and filtration and stored at 4 or $-20 \mathrm{C}$ for 1 week or analyzed immediately. See Materials and Methods for details. $\mathrm{NH},+\mathrm{NH},+$ was quantified by electrical conductance using an Alltech inorganic nitrogen analyzer. Data are the means \pm SE for two separate experiments.

Table 5. Effect of interruption of sample processing and storage for 1 week on leaf $\mathrm{NH}_{3}+\mathrm{NH}_{4}^{+}$content of oven-dried 'Washington' navel orange leaves.

\begin{tabular}{|c|c|c|}
\hline Treatment $^{2}$ & $\begin{array}{c}\text { Storage } \\
\text { temp } \\
\text { for } 1 \text { week }\end{array}$ & $\begin{array}{l}\mu \mathrm{gg} \mathrm{NH}_{4}^{+} / \mathrm{g} \\
\text { dry wt } \pm \mathrm{SE}\end{array}$ \\
\hline $\begin{array}{l}\text { Extracted }(1 \mathrm{~g} / 10 \mathrm{ml} 10 \% \mathrm{TCA}) \\
\text { analyzed immediately (control) }\end{array}$ & Not stored & $229 \pm 77$ \\
\hline Not extracted $(0.5 \mathrm{~g} / 5 \mathrm{ml} 10 \%$ TCA $)$ & $4 \mathrm{C}$ & $274 \pm 4$ \\
\hline Not extracted $(0.5 \mathrm{~g} / 5 \mathrm{ml} 10 \%$ TCA $)$ & $-20 \mathrm{C}$ & $235 \pm 4$ \\
\hline Extracted $(0.5 \mathrm{~g} / 10 \mathrm{ml} 10 \% \mathrm{TCA})$, filtered & $4 \mathrm{C}$ & $257 \pm 12$ \\
\hline Extracted $(0.5 \mathrm{~g} / 10 \mathrm{ml} 10 \%$ TCA $)$, filtered & $-20 \mathrm{C}$ & $245 \pm 6$ \\
\hline
\end{tabular}

Leaves, collected and washed as described in Materials and Methods, were oven-dried at $60 \mathrm{C}$ for $72 \mathrm{~h}$ and ground to pass through a 40-mesh screen. Samples were stored or processed through homogenization and filtration and stored at 4 or $-20 \mathrm{C}$ for 1 week. See Materials and Methods for details. $\mathrm{NH}_{3}+\mathrm{NH}_{4}^{+}$was quantified by electrical conductance using an Alltech inorganic nitrogen analyzer. Data are the means \pm SE for two separate experiments.

and puke nucleotides.

Given the results of this study, researchers and diagnostic laboratories must examine carefully the methods they use to measure $\mathrm{NH}_{3}+\mathrm{NH}_{4}^{+}$in plant tissue based on the accuracy required in the results relative to their intended purpose. Differences in sensitivity and interference from amino acids between methods should be considered when comparing data reported in the literature or interpreting threshold values, e.g., for ammonia toxicity.

\section{Literature Cited}

Adler, P.R. and G.E Wilcox. 1988. Influence of $\mathrm{NaCl}$ and $\mathrm{N}$ source on muskmelon growth and $\mathrm{NO}_{3}^{-}$and $\mathrm{NH}_{4}^{+}$accumulation. HortScience 23:765-766.

Barker, A.V. and R.J. Volk. 1964. Determination of ammonium, amide, amino, and nitrate nitrogen in plants extracts by amodified Kjeldahl method. Anal. Chem. 36:439$\begin{array}{lll}4 & 4 & 1\end{array}$

Berthelot, P. 1859. Violet d'aniline. Reportoire de Chimie Applique6 58: 284.

Bremner, J.M. 1965. Inorganic forms of nitrogen. In: C.A. Black (ed.). Methods of soil analysis. Agronomy 9:179-1237.

Brown, P.H. and Q.L. Zhang. 1993. Development of diagnostic measures of tree nitrogen status to optimize N fertilizer use. Proc. 2nd Annu. Fertilizer Res. and Educ. Program Conf., Davis, Calif, 9 Dec.

Burton, D.L., D.A. Gower, P.M. Rutherford, and W.B McGill. 1989. Amino acid interference with ammonium determination in soil extracts using the automated indophenol method. Commun. Soil Sci. Plant Anal. 20:555-565

Carlson, R.M. 1978. Automated separation and conductimetric determination of ammonia and dissolved carbon dioxide. Anal. Chem. 50:1528.

Feng, J. and A.V. Barker. 1992a. Ethylene evolution and ammonium accumulation by nutrient-stressed tomato plants. J. Plant Nutr. 15:137-153.

Feng, J. and A.V. Barker. 1992b. Ethylene evolution and ammonium accumulation by nutrient-stressed tomatoes grown with inhibitors of ethylene synthesis or action. J. Plant Nutr. 15:155-167.

Flares, H.E. and A.W. Galston. 1982. Polyamines and plant stress: activation of putrescine biosynthesis by osmotic shock. Science 217:1259-1261.

Frota, J.N.E. and T.C. Tucker. 1978. Salt and water stress influence nitrogen metabolism in red kidney beans. Soil Sci. Soc. Amer. J. 42:743-746.

Harrow, B., I.M. Chamelin, and H. Wagreich. 1933. The action of ammonia on phenols.
Science 78:514.

Kempers, A.J. 1974Determination of sub-microquantities of ammonium and nitrates in soils with phenol, sodiumitroprusside and hypochlorite. Geoderma 12:201-206.

Labanauskas, C.K. and M.F. Handy. 197 1. Protein and nonprotein amino acids in citrus leaves as affected by sample preparation and species differences. J. Amer. Soc. Hort. Sci. 96:514-518.

Lovatt, C.J., Y. Zheng, and K.D. Hake. 1988a. Demonstration of a change in nitrogen metabolism influencing flower initiation in Citrus. Israel J. Bot. 37:181-188.

Lovatt, C.J., Y. Zheng, and K.D. Hake. 1988b. A new look at the Kraus-Kraybill hypothesis and flowering of Citrus. Proc. 6th Intl. Citrus Cong. 1:475-483.

Lubochinsky, B. and J.P. Zalta. 1954. Microdosage colorimetrique de l'azote ammoniacal. Bull. Soc. Chim. Biol. 36:1363-1366.

McCullough, H. 1967. The determination of ammonia in whole blood by a direct calorimetric method. Clin. Chim. Acta. 17:297-304.

Monreal, C.M. and W.B. McGill. 1985. Centrifugal extraction and determination of free amino acids in soil solutions by TLC using tritiated 1-fluoro-2,4-dinitrobenzene. Soil Biol. Biochem. 17:533-539.

Nelson, D.W. 1983. Determination of ammonium in $\mathrm{KCl}$ extracts of soils by the salicylate method. Commun. Soil Sci. Plant Anal. 14:1051-1062.

Nilsen, E.T. and W.H. Muller. 1981. The influence of low water potential on the growth and nitrogen metabolism of the native California shrub Lotus scoparius (Nutt in T \& G) Ottley. Amer. J. Bot. 68:402-407.

Rabe, E. and C.J. Lovatt. 1984. De novo arginine biosynthesis in leaves of phosphorusdeficient Citrus and Poncirus species. Plant Physiol. 76:747-752.

Rabe, E. and C.J. Lovatt. 1986. Phosphorus deficiency results in a state of ammonia toxicity. Plant Physiol. 81:774-779.

Reardon, J., J.A. Foreman, and R.L. Searcy. 1966. New reactants for the calorimetric determination of ammonia. Clin. Chim. Acta. 14:403-405.

Searcy, R.L., J.A. Foreman, A. Ketz, and J. Reardon. 1967. A new automated method for urea nitrogen analysis. Amer. J. Clin. Pathol. 47:677-681.

Sehner-Olsen, A.R. 1971. Determination of ammonium in soil extract by an automated indophenol method. Analyst 96:565-568.

Van Slyke, D.D. and A. Hiller. 1933. Determination of ammoniain blood. J. Biol. Chem. 2:499-504.

Wall, L.L. and C.W. Gehrke. 1975. An automated total protein nitrogen method. J. Assn. Official Anal. Chemists 58:1221-1226.

Wall, L.L., C.W. Gehrke, T.E. Neuner, R.D. Cathey, and P.R. Rexroad. 1975. Total protein nitrogen: Evaluation and comparison of four different methods. J. Assn. Official Anal. Chemists 58:811-817. 